\title{
NLRP1 Gene
}

National Cancer Institute

\section{Source}

National Cancer Institute. NLRP1 Gene. NCI Thesaurus. Code C104538.

This gene plays a role in the induction of apoptosis. 